suspected. Archives of Disease in Childhood, 62, 11881195.

${ }^{14}$ Vizard, E., Bentovim, A. \& Tranter, M. (1987) Interviewing sexually abused children. Adoption and Fostering, 11, 20-25.

${ }^{15}$ MacFarlane, K., Waterman, J., Conerly, S., Daman, L., Durfee, M., \& Le LONG, S. (1982) Sexual Abuse of Young Children: Evaluation and Treatment. London: Guildford Press.

${ }^{16}$ Peters, S. D., Wyatt, G. E. \& Finkelhor, D. (1986) Prevalence. In A Sourcebook on Child Sexual Abuse (ed. D. Finkelhor) London: Sage Publications.

${ }^{17}$ CeCI, S., Toglia, M. P. \& Ross, D. (1987) Children's Eyewitness Memory. New York: Springer-Verlag.

${ }^{18}$ ARAJI, S. \& FinkELHOR, D. (1986) Abusers: a review of the research. In A Sourcebook on Child Sexual Abuse (ed. D. Finkelhor) London: Sage Publications.
${ }^{19}$ Wallerstein, J. S. \& Kelly, J. B. (1980) Surviving the Breakup: How Children and Parents Cope with Divorce. London: Grant MacIntyre.

${ }^{20}$ RutTer, M. (1980) Psychosexual development. In Scientific Foundations of Developmental Psychiatry (ed. M. Rutter) London: Heinemann.

${ }^{21}$ Bentovim, A., Elton, A., Hildebrand, J., Tranter, M. \& Vizard, E. (1988) Child Sexual Abuse within the Family: Assessment and Treatment. London: John Wright.

${ }^{22}$ JoNEs, D. P. H. \& McGraw, J. M. (1987) Reliable and fictitious accounts of sexual abuse in children. Journal of Interpersonal Violence, 2, 27-45.

Approved by Council

October 1988

\title{
The Seventeenth Annual Meeting, 1988
}

The Seventeenth Annual Meeting of the College was held in Brighton on 5, 6, and 7 July under the Presidency of J. L. T. Birley.

\section{Scientific Meetings}

The Scientific Meetings were held at the Brighton Metropole Hotel.

\section{Business Meeting}

The Business Meeting was held on 6 July and was chaired by Dr J. L. T. Birley. It was attended by 110 Members of the College.

The minutes of the previous meeting held in Belfast on 1 July 1987 and published in the Bulletin, December 1987 were approved and signed.

The Report of the Registrar and the Annual Report were received and approved.

The Report of the Treasurer and the Annual Accounts for 1987 were received and approved.

The appointment of auditors was approved.

\section{Registrar's Report}

You will all have received copies of the Annual Report. I am going to tell you about the various College activities which have occurred since the Report went to print at the beginning of May.

The Working Party, chaired by the President and convened to prepare the College's response to Sir Roy Griffiths Report Community Care: An Agenda for Action, submitted its report to Council in June.
The College is concerned not only about many of the proposals in this report but also about its underlying assumptions. In particular, we have not supported the key recommendation that local authorities take responsibility for assessing needs and providing community care for the mentally ill. Our comments have been forwarded to the Secretary of State for Social Services, have been widely circulated and will be published in the September Bulletin.

The College has recently completed another successful JPAC exercise in its applications for extra senior registrars in forensic psychiatry and mental handicap psychiatry; 15 extra posts in forensic psychiatry and 22 extra mental handicap posts have been approved. The College's Working Party on JPAC is now considering the number of registrar posts required in the specialty over the next ten years and we have been invited to present our report to JPAC in the middle of September.

Council has approved the establishment of a permanent Appeals Office to extend the College's fund-raising activities. Dr Michael Pare has been appointed Appeals Director. A new Appeals Committee will be established under the chairmanship of an influential non-psychiatrist and with a membership drawn from all walks of life. The first priority of the Appeals Office will be to secure the permanent establishment of the College's Research Unit. I should add that covenant forms for the Appeal are, as always, available from the Registration Desk.

I am pleased to report that Professor Brice Pitt has agreed to replace Dr Michael Pare as the College's Public Education Officer. 
The Special Committee on Psychiatric Practice and Training in a British Multi-Ethnic Society, convened by Council under the chairmanship of Professor K. Rawnsley, was due to present its report this summer. Council has agreed to extend this deadline for one year.

The Law Society is to convene a major conference on Child Sexual Abuse on 23 September 1988. All members of the College are welcome to attend this and details are available from 17 Belgrave Square.

The new Chairman of the Mental Health Act Commission Mr Louis Blom-Cooper, visited the College and met with Council members last month. There was a positive exchange of views and we were also pleased to welcome the new Vice-Chairman, Professor Elaine Murphy.

I am very pleased to announce that Dr Thomas Bewley has recently been awarded an Honorary CBE.

Members of the College will be interested to receive the following election results.

\begin{tabular}{|c|c|}
\hline \multicolumn{2}{|l|}{ Sections } \\
\hline $\begin{array}{l}\text { Forensic Psychiatry Specialist } \\
\text { Section }\end{array}$ & $\begin{array}{l}\text { Dr A. Campbell } \\
\text { (Chairman) }\end{array}$ \\
\hline $\begin{array}{l}\text { Section for the Psychiatry of } \\
\text { Mental Handicap }\end{array}$ & $\begin{array}{l}\text { Dr D. Wilson } \\
\text { (Secretary) }\end{array}$ \\
\hline Psychotherapy Specialist Section & $\begin{array}{l}\text { Dr S. Grant } \\
\text { (Secretary) }\end{array}$ \\
\hline $\begin{array}{l}\text { Section for Social \& Community } \\
\text { Psychiatry }\end{array}$ & $\begin{array}{l}\text { Dr D. Fowlie } \\
\text { (Chairman) } \\
\text { Dr T. Burns } \\
\text { (Secretary) }\end{array}$ \\
\hline \multicolumn{2}{|l|}{ Divisions } \\
\hline North East Division: & $\begin{array}{l}\text { Dr D. A. } \\
\text { Stephens } \\
\text { (Chairman) }\end{array}$ \\
\hline Southern: & $\begin{array}{l}\text { Dr J. Cockburn } \\
\text { (Chairman) } \\
\text { Dr J. Connolly } \\
\text { (Secretary) }\end{array}$ \\
\hline
\end{tabular}

This is, as many of you will know, my last Report as Registrar. I am sure that you will all join me in wishing my successor, Dr Ann Gath, every good wish.

\section{Resolutions}

The following Resolution as set out in the notice convening the meeting was proposed by Dr J. L. T. Birley and seconded by Dr W. A. G. MacCallum:

"That the Bye-laws of the College be amended, revoked and added to in accordance with the copy thereof containing such amendments, revocations and additions sent to the Members with the Notice of this Meeting provided that such amendments, revocations or additions shall not take effect until the same shall have been approved by the Privy Council and provided further that the Executive any Finance Committee of the Council shall have authority to approve any further amendments required thereto by the Privy Council".

The Resolution was then put to the meeting and approved by a simple majority but not by the necessary majority of not less than two thirds of the members present and voting and was accordingly not carried.

Professor M. Hamilton proposed that the Treasurer should continue to be elected from amongst the Fellows by the Members of the College [Bye-law XII (2)]. This was seconded by Professor H. Freeman. This proposal was then put to the meeting and carried by a majority of the members present.

Dr P. Rice proposed that Council re-consider the amendment to Bye-law III 2(ii). This was seconded by $\mathrm{Dr}$ I. Medley. This proposal was then put to the meeting and as more than two thirds of the members voted against the proposal, was declared not carried.

Dr J. L. T. Birley then proposed that having taken the advice of the Solicitor to the College who was present at the meeting that it would be in order for the meeting to approve the alterations to the Bye-laws proposed in the Resolution set out in the notice of the meeting with the exception of the alterations proposed by Bye-law XII, the meeting should approve the Resolution amended as follows:

"That the Bye-laws of the College be amended, revoked and added to in accordance with the copy thereof containing such amendments, revocations and additions sent to the Members of the College with the notice of this Meeting (but with the exception of the proposed amendment to Bye-law XII) provided that such amendments, revocations or additions shall not take effect until the same shall have been approved by the Privy Council and provided further that the Executive and Finance Committee of the Council shall have authority to approve any further amendments required thereto by the Privy Council".

Dr W. A. G. MacCallum seconded the proposal and the Resolution as amended was then put to the meeting and carried unanimously.

The following Resolution, proposed by Dr S. D. Bloch and seconded by Dr R. G. Poole was carried unanimously:

"Recalling the General Assembly's resolutions of 1977 and 1983 about the abuse of psychiatry for political purposes, the Royal College of Psychiatrists proposes that the All-Union Society of Psychiatrists and Neuropathologists of the USSR should only be invited to rejoin the World Psychiatric Association when the following conditions have been met:

(1) The Authorities have dissociated themselves from past abuses and taken effective action to prevent their repetition.

(2) All individuals detained unjustifiably in psychiatric institutions have been released". 


\section{Election and introduction of Honorary Fellows}

The following were unanimously welcomed to the Honorary Fellowship.

\section{Professor Irving Gottesman (introduced by Dr Robin M. Murray)}

Anyone who picks up a copy of the Archives of General Psychiatry in 1988 cannot fail to be impressed by the current strength of American psychiatric research and by the prominent role allotted to psychiatric genetics. However, both of these are relatively recent phenomena, and when Irving Gottesman qualified from the University of Minnesota as a clinical psychologist in 1960, American psychiatric research was in the doldrums. Indeed, Professor Michael Shepherd had just caused considerable controversy by criticising it strenuously for its insularity, its preoccupation with psychoanalysis, and the widespread ignorance of the contribution of heredity to psychiatric disorders. So as a psychologist, Irving Gottesman showed considerable independence of mind in deciding to enter psychiatric research, and in particular the then dangerous waters of psychiatric genetics. He had, however, been a midshipman and then an officer in the US Navy for six years before entering psychology so the prospect of poorly charted seas ahead did not deter him. He compounded his sins in the eyes of the orthodox by taking the unusual step of coming to England for his further training, and in 1963 he became an NIMH Special Fellow in psychiatric genetics at the Maudsley Hospital. The attraction was, of course, the MRC Unit run by Eliot Slater, and there Irv Gottesman developed what became a lifelong interest in the genetics of schizophrenia.

The study of schizophrenic twins which he undertook with James Shields is far too well known for me to review it here. It is simply the landmark study to which all others have been compared and found wanting. However, I would just remind you of the two most important innovations which Irving Gottesman introduced. Firstly, the idea of blind diagnosis made on the twins by a range of psychiatrists not only with different perspectives from the biological to the social but also from different countries. Secondly, it was he who brought into psychiatry the idea of the polygenic multifactorial hypothesis which was to dominate genetic theorising about psychiatric disorder for almost 20 years. This study has, of course, produced many influential papers and is summarised in the 1972 book on Schizophrenia and Genetics. Although the credit for this study belongs wholly to Gottesman and Shields, some smart person persuaded them to call it the 'Maudsley Twin Study' and therefore allowed the Maudsley to bask in the reflected glory for the sub- sequent two decades. Indeed, even now I am sometimes asked whether Professor Gottesman still works at the Maudsley.

In the meantime Irving Gottesman had returned to the United States, and rapidly rose to become Professor and Director of the Behaviour Genetics Centre at the University of Minnesota. For a long period, when psychiatric genetics was not as fashionable as it is today, he was one of only two or three distinguished individuals who kept it on the American psychiatric map. Professor Gottesman has always been the first to acknowledge the debt he owed to his British colleagues; he and James Shields edited Slater's selected papers in 1971, and published them as the book Man, Mind and Heredity. It is, of course, almost impossible to think of Irving Gottesman without mentally attaching the name of James Shields. So close were they that they regarded each other as at least dizygotic twins, and in 1982 Irv Gottesman paid posthumous tribute to his colleague, who had died four years earlier, by publishing the widely praised book Schizophrenia - The Epigenetic Puzzle in their joint names. This was, I think, a characteristically generous action.

Professor Gottesman moved to Washington University, St Louis, in 1980, and then in a very productive collaboration with mathematic and statistical geneticists published a series of elegant papers on the mode of inheritance of schizophrenia. These studies examined many issues such as whether the twin and family data support a single locus model for schizophrenia, or a multifactorial threshhold model, or indeed whether a mixed model combining elements of both is more appropriate. More recently he has been conducting fascinating work with Danish colleagues on the offspring of parents, both of whom are psychotic. Professor Gottesman is now Commonwealth Professor of Psychology at the University of Virginia and has achieved many distinctions. I shall not list them all but simply say that within the last year he was selected to be one of the Distinguished Fellows at the Centre of Advanced Study in the Behavioural Sciences at Stanford, and he has also received the Stanley Dean award for contributions to the understanding of schizophrenia.

But more important than these, he has the accolade of being the psychiatric geneticist who makes complicated genetic theory intelligible to the ordinary psychiatrist. His articles and reviews are eminently readable, and frequently are announced with such intriguing titles that even the most committed environmentalist must feel compelled to read on, even against his will. Typical examples are 'The Psychotic Hinterlands or the Fringes of Lunacy', 'Schizophrenia and Genetics: Where are we? Are you Sure?'; or 'Double talk for Twins' Mothers'.

Professor Gottesman has been proud of being an associate member of the College since its inception 
and has been particularly helpful to those of us who have attempted to revive psychiatric genetics this side of the Atlantic. In electing Irving Gottesman to the Honorary Fellowship, the College is strengthening its links with psychology, it is honouring a distinguished American, it is recognising the vital importance of genetic research, but above all it is taking a small step to repay the attention and esteem that Irv Gottesman's twin study and partnership with James Shields brought to British psychiatry.

Professor Robert Hinde (introduced by Dr S. N. Wolkind)

When I wrote to Robert Hinde to tell him I had been given the pleasure of introducing him to the College, he replied that he hated introductions and that I should not make it too long. He added however, that he was pleased about the proposed election. It made him feel he was "moving towards respectability". This surely should make us pause and think about the potential power of respectability that our Honorary Fellowship can confer. Robert has already been awarded honorary status by, amongst others, organisations as diverse as the National Academy of Sciences, the British Psychological Society, and the American Ornithologist Union. His many awards include the Albert Einstein award for Psychiatry, the Osman Hill Medal of the Primate Society of Britain and the Zoological Society's Scientific Medal. He is a fellow of the Royal Society and a Commander of the British Empire.

Robert Hinde is Honorary Director of the Medical Research Unit on the Development and Integration of Behaviour and a Royal Society Research Professor. He began his career as a zoologist in 1948. The first spate of his very many important scientific papers were devoted predominantly to studies of the behaviour of birds. One can only speculate whether this choice of class was determined by his having become an RAF pilot at the impressionable age of 17 , spending five years in the skies during World War II. This early work demonstrated that the careful observation of behaviour often in a natural setting, was a potent scientific tool, as precise as any form of laboratory investigation. He brought all his early work together and examined its theoretical implications in 1966, in his important book Animal Behaviour which he subtitled A Synthesis of Ethology and Comparative Psychology.

In 1972, he began his Directorship of the Medical Research Council Unit at Madingly and with it appeared to make a dramatic leap up the evolutionary scale, devoting most of his early studies there, to primates. It rapidly became clear that the work he and his team, at Madingly were doing had major implications for human psychology and psychiatry. His work on mother-infant interactions and on the effects of separation greatly influenced many in our speciality. John Bowlby has described how much his thinking on attachment was guided by Robert's work. Equally Robert Hinde and his colleagues realised their ethological concepts could be profitably used to study many aspects of human behaviour and relationships. His empirical studies, many conducted with Joan Stevenson-Hinde, are major contributions to human developmental psychology. His theoretical contributions have been immense. His 1979 book, Towards Understanding Relationships examined the complex interplay between personality, relationships and the social environment. His writings have given new meaning to terms such as 'family dynamics', which can so easily be used in a sloppy and unthinking way.

Robert Hinde's scientific contributions alone make him an obvious choice for an Honorary Fellowship. In addition however, we should note what he has already done for our College. He has been a regular contributor at College meetings gracing them with his lucid and elegant lectures. On an individual level he has been unstinting of his time, giving advice and encouragement to young psychiatrists wishing to start research projects of their own. A trip to Madingly will surely have been a major scientific experience of many who are here today.

It is truly a privilege to present Professor Robert Hinde to you now for the Honorary Fellowship of our College.

\section{Dr Jozé Jancar (introduced by Dr K. A. Day)}

It is a special pleasure and privilege to introduce $\mathrm{Dr}$ Jozé Jancar, my teacher, mentor and friend, and wholly fitting that the College should mark the retirement of one of its most senior and distinguished members in the field of mental handicap with the award of an Honorary Fellowship.

Dr Jancar has been a distinguished member of the College since its inception and has served on all major College Committees. He was Vice-President from 1981 to 1983 and an outstanding Chairman of the Section for the Psychiatry of Mental Handicap when he was a pivotal force both within and without the College in establishing the specialty of the Psychiatry of Mental Handicap on a firm footing at a time when its very survival was being seriously questioned. The four years of his Chairmanship for 1979 to 1983 saw a remarkable turn-around from uncertainty, low morale and apathy to a new found enthusiasm, optimism and improved recruitment with mental handicap once again raised to a high profile within the College. Such was his impact that the College's first Secretary - the late Natalie Cobbing, bequeathed a substantial sum of money to the College on her death specifically for use in the field of mental handicap, enabling the establishment of the Natalie Cobbing Travelling Fellowship.

A much loved figure in Bristol where he was con- 
sultant at the Stoke Park Hospital Group for 25 years until his retirement in 1985, Jozé, together with his colleagues built on the long and distinguished tradition which Bristol has in research and service provision in mental handicap, pioneering new approaches and establishing an enviable service with some of the best facilities in the country. With his strong sense of history and love of tradition he has chronicled the history of the Bristol mental handicap services, was a prime mover in establishing the Burden Gold Medal and Prize for research in mental handicap in 1969 - honouring the Victorian benefactors of Stoke Park Hospital on its Diamond Jubilee and always has a pertinent quote - usually from the classics, for all occasions. An influential and respected member of the general medical scene in Bristol, he was particularly proud to be elected the President in 1985 of the Bristol Medico-Chirurgical Society - one of the oldest medical societies in the United Kingdom.

Equally active and influential at national and international level, he was a member of the Mental Health Act Commission from its inception, Chairman of the Mental Health Group of the British Medical Association, Council Member and Chairman of the Research Committee of the International Association for the Scientific Study of Mental Deficiency and a Member of Council of the Psychiatric Section of the Royal Society of Medicine where again he was a prime mover in establishing the highly successful Forum on Mental Retardation which brings together a range of disciplines in the presentation of high quality research in all aspects of mental handicap. A researcher himself all his life he has contributed extensively to the literature on mental handicap and is author and co-author of a number of books and chapters and many scientific papers. His main interests have been in the biochemical, cytological and organic aspects of mental handicap and his book with Dr Eastham on Clinical Pathology in Mental Retardation is a recognised classic which has been translated into Italian. More recently he has pioneered research into morbidity, mortality and ageing in the mentally handicapped.

Jozé has been variously honoured in this country and abroad. He was awarded the Burden Research Gold Medal and Prize in 1971, delivered the Blake Marsh Lecture in 1974 and received the Distinguished Achievement Award for Scientific Literature of the International Association for the Scientific Study of Mental Deficiency in 1985. In 1980 he was elected a Liveryman of the Worshipful Society of Apothecaries of London and a Freeman of the City of London. In addition to being able to vote at the annual election of the Lord Mayor, this confers the privilege of being able to drive one's sheep across London Bridge - a task which in the unlikely event of his ever having to undertake he would undoubt- edly accomplish with consummate ease in view of the leadership qualities and fortitude he has displayed throughout his professional life.

Mr President, Dr Jancar has made his mark in this country and internationally as a clinician, teacher and researcher. In a life devoted to his subject he has pursued with tireless energy, enthusiasm and determination the improvement of the care and treatment of mentally handicapped people and their families everywhere. He has given selfless encouragement to young researchers both sharing and stimulating ideas and generous unstinting support and advice to colleagues everywhere. By any standards his achievements are considerable, but they are made all the more remarkable when one learns that he came to this country in $1948-40$ years ago next month, a young, married, final year medical student forced to flee his native country Yugoslavia - to which he has never been able to return, with no more than a smattering of English and a very uncertain future. With characteristic fortitude he obtained employment as a nursing assistant in one of the Bristol mental handicap hospitals - thereby kindling an interest which has never left him, completed his medical education in Galway and Dublin and returned to Bristol in 1956 to take a junior medical post at the hospital where he has worked all his professional life, eventually becoming the senior consultant.

His trials and tribulations, successes and achievements have been shared by his wife Maria - herself a young medical student at the time of leaving Yugoslavia. We are all delighted, I am sure, that she is here today to share this honour with him.

\section{Dame Cicely Saunders (introduced by Professor A. H. Crisp)}

Dame Cicely was caring for others professionally long before she became a doctor. This lifelong determination undoubtedly led her, between pre-war and wartime years at St Anne's College, Oxford, to qualify SRN at St Thomas's Hospital, inevitably with distinction. By 1945 she had also gained a BA in Public and Social Administration (with distinction). By 1947 she had also qualified as an almoner. Not until 1951, at the age of 33, did she enter Medical School at St Thomas's. In 1957 she qualified MB BS (with Honours in Surgery). Perhaps Dame Cicely studied medicine to secure the authority to prescribe, an understanding and requirement she recognised by then as being altogether necessary in her work. Within a year she was embarked on her subsequent life-long care of the dying, initially focusing on pain relief and control with drugs but, as always, bearing all her patients' needs in mind.

Her biography, written by Shirley du Boulay, ${ }^{1}$ charts her life in a splendidly frank and delightful readable way. It is a story of the human spirit and can be commended to one and all to read. 
By $1961 \mathrm{St}$ Christopher's Hospice was registered as a charity. Dame Cicely's fight to secure the site and property makes stirring reading. She was Medical Director of the Hospice from 1967 to 1985 and, since then, has been its Chairperson.

Dame Cicely has a deep understanding of human need. She was one of the first within modern medicine, perhaps along with John Hinton, one of our distinguished fellow psychiatrists, to hear what dying patients said. As her understanding grew she embraced also the families in her professional concern and care. For many years she has worked sympathetically with psychiatrists; in particular, with Colin Murray Parkes and John Hinton.

Her writings are multitudinous and durable. They are to be found within the wide range of medical, nursing and related publications. She has developed St Christopher's to be a world centre of teaching and research and her capacity to communicate her knowledge and skills and to inspire others is such that the hospice movement has become worldwide in less that three decades. She is its acknowledged leader. Thus her combination of perceptiveness and Christian vocation has enabled her to alter the practice in a whole field of medicine in her own lifetime.

She has been awarded more than a dozen honorary higher doctorates. Inevitably first recognised abroad, she began in style with the first of these doctorates, DSc, conferred by Yale in 1969. Both Oxford and Cambridge have now joined the ranks.

In 1974 she was elected FRCP. In 1981 she became FRCN and in 1986, FRCS. OBE in 1967, she became DBE in the New Year's Honours List of 1980. She has numerous other distinctions. She also has those basic understandings and attributes that we as psychiatrists strive for. For her to be a Fellow of our College undoubtedly adds great lustre to it.

\section{Reference}

'Du Boulay, ShIRLEy (1984) Cicely Saunders, The Founder of the Modern Hospice Movement. London: Hodder \& Stoughton.

\section{Mrs Renée Short (introduced by Professor Robert Bluglass}

It is my honour and privilege to present to you Mrs Renée Short, Member of Parliament for Wolverhampton North-East from 1964-1987. She is, I believe, the first Parliamentarian to be honoured with our Fellowship and this is in recognition of an unparalleled contribution to the health and social services of this country from a backbencher.

She received her education at Manchester University, where she developed a taste for the theatre, so that her early career was as a stage designer. Her political roots and origins date from 1948 and the foundation of the National Health Service when she joined the Labour Party and became a disciple of Aneurin Bevan. In this week when some are celebrating the 40th anniversary of the NHS her election is perhaps a particularly happy coincidence. She was also elected to Hertfordshire County Council where she served for 15 years, and to Watford Rural District Council, where she served for 12 years, and this led to appointments to Hospital Management Committees and to practical experience of the National Health Service. In October 1964 she was elected to Parliament and soon established a reputation as a formidable and outspoken battler and campaigner on a wide range of issues from sponsorship of the Abortion Law Reform Bill in 1965 to pressure for a channel tunnel in 1968, the right for Sikhs to be allowed to wear their turbans in 1969 and a resounding speech in May 1970 when she urged a square deal for women with big feet (having assumed her role as their champion as she had the proud reputation as the woman MP with the largest feet).

Her interests, however, were always primarily, and particularly, with issues relating to health and social services in the widest sense. She was a member of the Expenditure Committee of the House of Commons from 1970 to 1979 and chaired its Social Services and Employment Sub-Committee, predecessor of the House of Commons Select Committee on Social Services, which she chaired, with great distinction, from 1979 until her retirement at the general election in 1987.

Renée Short, therefore, presided over the key parliamentary committee which monitors the expenditure, administration and policy of the DHSS and associated public bodies, during an unbroken 21 years. This must itself be something of a parliamentary record and it is certainly a record of endurance. During this time she has skilfully chaired a committee with a majority of Conservative members of Parliament and it was a credit to her chairmanship that the committee was able to reach a consensus on every one of the 28 reports which have been produced since 1979. Her bibliography during this time seemed to encompass, at one time or another almost every aspect of health care and social provision in Britain. Her major reports include, for instance, that on Perinatal and Neonatal Mortality, Medical Education, on University Grants Committee Cuts and Medical Services, Age of Retirement, Children in Care, Community Care, with special reference to adult mentally ill and mentally handicapped people, (with its memorable aphorism "any fool can close a hospital"), Misuse of Drugs, Reform of Social Security, the Prison Medical Service, Primary Health Care and, finally, the outstanding report on the problems associated with AIDS which just made publication before the dissolution of Parliament in 1987. These Short Reports were by no means necess- 
arily brief but always studious and authoritative, a valuable source long after their publication. They were not simply valuable texts, they were always thoughtful and realistic with recommendations that were modest and practical, rather than necessarily radical or controversial. Their influence will continue well into the future.

This unique achievement is a tribute to Mrs Short's energy and personality and to her evolving position as the matriarch of a disparate group of MPs of many colours, all of whom, together with a succession of expert advisers who served the Committee over many years, held her in enormously loyal affection. I was in a position to observe this at first hand when I accompanied the Committee, under her leadership, on a tour to Sweden and Holland, an experience which I shall long remember and which closely resembled a school trip of high-spirited boys freed for a time from classes, firmly led by their benevolent and highly good humoured headmistress. On Wednesday afternoons in the House of Commons she and her Committee never shrank from probing those, including Ministers, who were suspected of economy in revealing important information.

On her retirement she found it painful to be separated from her Committee and all the inquiries which she would still wish to initiate and pursue. She was honoured at a gathering of all those who had been members of the Committee or its advisers during the many years she had been in the chair, including the presence of $\mathrm{Mr}$ Speaker. Now she has undertaken a new challenge as a Member of the Medical Research Council and is busily taking on other new commitments.

There is no doubt, however, that her reports and influence have made an enduring mark upon the future development and direction of health care, psychiatry and medico-politics.

Mr President, for her distinguished service over many years, it is my privilege to present to you for the Award of Honorary Fellowship of the Royal College of Psychiatrists, Mrs Renée Short.

\section{Section for the Psychiatry of Mental Handicap}

\section{Guidelines for Regional Representatives}

\section{Roles and duties}

Regional Representatives are internal College appointments to assist Regional Advisers and the Chairman of the Section in a variety of matters. The official representatives of the College at Regional level are Regional Advisers.

Regional Advisers are expected to consult Regional Representatives on the following matters:

job descriptions for senior registrar posts and consultant posts in mental handicap;

nominations to serve on Appointments Committees for senior registrars in England and Wales;

other aspects of services and the implementations of College policy.

Officers of the Section for the Psychiatry of Mental Handicap may consult Regional Representatives on the following matters:

nominations for distinction awards;

nominations for Fellowship;

other aspects of services and implementation of College policy.
Regional Representatives are expected to alert/ consult with the Chairman on any local issues of potentially national importance in relation to services for the mentally handicapped.

\section{Useful reference documents}

Royal College of Psychiatrists (1983) Mental handicap services - the future. Bulletin of the Royal College of Psychiatrists, 7, 131-134.

-(1985) Registrar training in mental handicap. Bulletin of the Royal College of Psychiatrists, 9, 206.

-(1985) Guidelines for regional advisers on consultant psychiatrist posts in mental handicap. Bulletin of the Royal. College of Psychiatrists, 9, 207-208.

-(1986) Psychiatric services for mentally handicapped adults and young people. Bulletin of the Royal College of Psychiatrists, 10, 321322. 